\title{
Different LF and HF HRV responses to cold pressor test in normotensive and prehypertensive men
}

\author{
Vera E. Shekh*, \\ Emeka Idot-Eyin Ofoegbu, \\ Ebunoluwa Grace Adenuga, \\ Larisa S. Shchyrova \\ Department of Human \\ and Animal Physiology, \\ V. N. Karazin Kharkiv \\ National University, \\ 4 Svobody Sq., \\ Kharkiv 61022, Ukraine
}

\begin{abstract}
Hypertension is a global health problem and a risk factor of cardiovascular disease, cerebrovascular and kidney disease. The cold pressor test (CPT) is commonly used as a sympathoexcitatory manoeuvre. Heart rate variability (HRV) is a useful tool for assessment of autonomic nervous system activity. The aim of this study was to evaluate cardiovascular and HRV responsiveness to $\mathrm{CPT}$ in 46 normotensive and 25 prehypertensive (PHT) young man. In ECG was recorded at rest and CPT for 5 min each to evaluate heart rate (HR), total power (TP), low frequency (LF) and high frequency (HF) power. General linear model was used to test for effect of prehypertension and CPT on HR, systolic blood pressure (SBP), diastolic blood pressure (DBP) and HRV variables and their responses to cold. The stepwise multiple linear regression analysis was used to reveal predictors of $\triangle \mathrm{HR}, \triangle \mathrm{SBP}$ and $\triangle \mathrm{DBP}$. All analyses were conducted using SPSS 22. Blood pressure responsiveness to CPT was not associated with PHT; instead, it was associated with BMI. The $\triangle \mathrm{HR}, \triangle \mathrm{SBP}$, and $\triangle \mathrm{DBP}$ were not significantly different between normotensive and prehypertensive subjects. However, $\Delta \mathrm{LnTP}, \Delta \mathrm{LnLF}$, and $\Delta \mathrm{LnHF}$ were significantly higher in normotensives than in prehypertensives: LnTP, LnLF, and LnHF increased in normotensive subjects while these indices decreased in prehypertensives.
\end{abstract}

Keywords: prehypertension; cold pressor test; HRV

\section{INTRODUCTION}

Hypertension is an important global health problem and a common risk factor of cardiovascular disease, chronic kidney disease, and premature death (Schroeder et al., 2003; Mills et al., 2016). That is why an early diagnostic and awareness of

* Corresponding author. Email: vshekh@karazin.ua; verashekh@gmail.com hypertension are necessary for its control and prevention from further development by means of pharmacological and such non-pharmacological treatment as slow breathing, a change of life style (diet, fresh outdoor air, exercise) are a very important task for medical and biological science.

Evidence from previous studies suggests that the impairment of autonomic nervous system plays an important role in pathophysiology of hypertension and that autonomic dysfunction 
underlies the initiation and development of hypertension (Wu et al., 2008; Schroeder et al., 2003). HRV is a potentially useful non-invasive tool to assess the cardiac autonomic function and its contribution to the cardiac function in health and disease (Task Force of the European Society of Cardiology, and the North American Society of Pacing and Electrophysiology, 1996). High-frequency HRV power (HF) is widely accepted as a measure of cardiovagal activity, however, the interpretation of the low-frequency HRV power (LF) is more controversial. Our interpretation of LF HRV power described previously (Shekh, 2018) extends observations in that LF power is an index of the baroreflex modulation of cardiac autonomic outflows (Goldstein et al., 2011), namely, that LF oscillations of HRV represent sympathoinhibitory arm of the baroreflex (Shekh, 2018a).

The cold pressor test (CPT) is commonly used as a sympathoexcitatory manoeuvre for the evaluation of cardiovascular reactivity to stress (Loyke, 1995; Lambert, Schlaich, 2004; Farah et al., 2011; Cheung, 2015). Some of previous reports demonstrated that rise of blood pressure during CPT was significantly higher in subjects with a family history of hypertension (Farah et al., 2011), in hypertensive (Loyke, 1995), and atherosclerotic patients (Voudoukis, 1977). These authors hypothesized that cardiovascular hyperreactivity to cold stress is an important risk factor for the development of hypertension and thus the CPT may be employed as an indicator of the severity of hypertension and atherosclerosis. However, the use of the CPT as a predictor test of future hypertension is still debatable because in some other reports it was shown that the cardiovascular reactivity to the CPT did not differ between normotensive subjects and hypertensive patients (Czarkowski et al., 1994), or even CPT-induced decrement in blood pressure and sympathetic responses were subnormal in hypertensive patients compared with normotensive participants (Lambert, Schlaich, 2004; Shekh, 2018).

The aim of this study was to compare the cardiovascular and HRV responses to the CPT in normotensive and prehypertensive young men.

\section{MATERIALS AND METHODS}

A cohort of 46 normotensive SBP $=115.41 \pm$ $1.01 \mathrm{~mm} \mathrm{Hg}$ ) and 25 prehypertensive ( $\mathrm{SBP}=$ $129.10 \pm 1.63 \mathrm{~mm} \mathrm{Hg}$ ) subjects were enrolled from the population of Indian students at V. N. Karazin Kharkiv National University. All of them gave written informed consent. There were no significant differences in age and height between normotensive and prehypertensive groups (not shown). However, the body mass index (BMI) was significantly higher in prehypertensive subjects than in normotensives $(P<0.010)$.

The ECG was continually recorded during a 5-minute resting stage following a stabilization period and the cold pressor test. The CPT was done by the immersion of the right hand into ice-cold water for five minutes. HR was obtained by digital 12-channel ECG amplifier with a sampling frequency of $1000 \mathrm{~Hz}$ (CardioLab 2010, XAI-Medica, Ukraine) (Shekh, 2016). SBP and the diastolic blood pressure (DBP) were recorded by means of the automatic blood pressure digital sphygmomanometer (Nissei WS-1011, Nihon Seimitsu Sokki Co., Ltd, Japan).

The nonparametric method of fast Fourier transformation was used to represent the signal in the frequency domain. The total power (TP), low frequency, and high frequency HRV power were expressed in absolute units. For their interpretation we proceeded from the assumption that HF power received from 0.15 to $0.40 \mathrm{~Hz}$ oscillations was a measure of the cardiovagal outflow (Task Force of the European Society of Cardiology, and the North American Society of Pacing and Electrophysiology, 1996; Goldstein et al., 2011; Shaffer and Ginsberg, 2017), LF power computed from low-frequency oscillations ranging from 0.04 to $0.15 \mathrm{~Hz}$ was the sympathoinhibitory baroreflex-mediated index of cardiac autonomic regulation (Shekh, 2018a; Goldstein et al., 2011), and TP was a sum of the energy in the very low frequency (VLF), LF, and HF bands for short-term recordings (Shaffer and Ginsberg, 2017).

The two-way repeated-measure MANOVA was used to test for effects of prehypertension 
(PHT) and cold stress on the heart rate, systolic blood pressure, diastolic blood pressure, natural logarithm of total power, low-frequency and high-frequency HRV power. If the data were not normally distributed, the outcome variables were naturally log-transformed (TP, LF and HF power) to meet assumptions for repeated-measure MANOVA. The one-way MANOVA was used to test for the effect of PHT on HR, SBP, DBP, LnTP, LnLF, and LnHF HRV power responses to immersion of the hand into ice-cold water. Since the BMI was different between normotensive and prehypertensive subjects, a two-way repeated-measure MANCOVA with the BMI as a covariate was used for the comparison of $H R$, SBP, DBP, LnTP, LnLF, and LnHF. Simple effects were tested by means of SPSS command syntax with Bonferroni correction. The stepwise multiple linear regression analysis was used to reveal predictors of $\triangle \mathrm{HR}, \triangle \mathrm{SBP}$ and $\triangle \mathrm{DBP}$. The data are expressed as means $\pm \mathrm{SE}$. All analyses were done by means of SPSS 22 .

\section{RESULTS}

During the cold pressor test the heart rate increased in both normotensive and prehypertensive subjects (not shown). No significant differences in HR were found between the nor- motensives and prehypertensives at rest or during immersion of the hand into ice-cold water.

The immersion of the hand into ice-cold water led to a significant increase in both systolic and diastolic blood pressure in normotensive and prehypertensive subjects (Fig. 1). According to inclusion criteria the SBP and DBP was higher in prehypertensives compared with normotensive subjects (Figs. $1 \mathrm{~A}$ and $1 \mathrm{~B}$, respectively). However, the increment of SBP and DBP was not significantly different between normotensives and prehypertensives.

Despite the absence of significant differences between normotensives and prehypertensives in the LnTP conceded as a sum of the energy in the VLF, LF, and HF bands, at rest and during cold pressor test, the LnTP significantly increased only in the normotensive group, while in prehypertensive group it even tended to decrease (Fig. 2). Similarly, LnLF and LnHF power increased in normotensive and decreased in prehypertensive subjects (Fig. 3). All frequency domain indices analysed in the current study increased in the normotensive group and decreased in prehypertensives so much that the differences in $\triangle \mathrm{LnLF}$ and $\triangle \mathrm{LnHF}$ power, as well as $\Delta$ LnTP between normotensive and prehypertensive subjects, were statistically significant (Fig. 3).

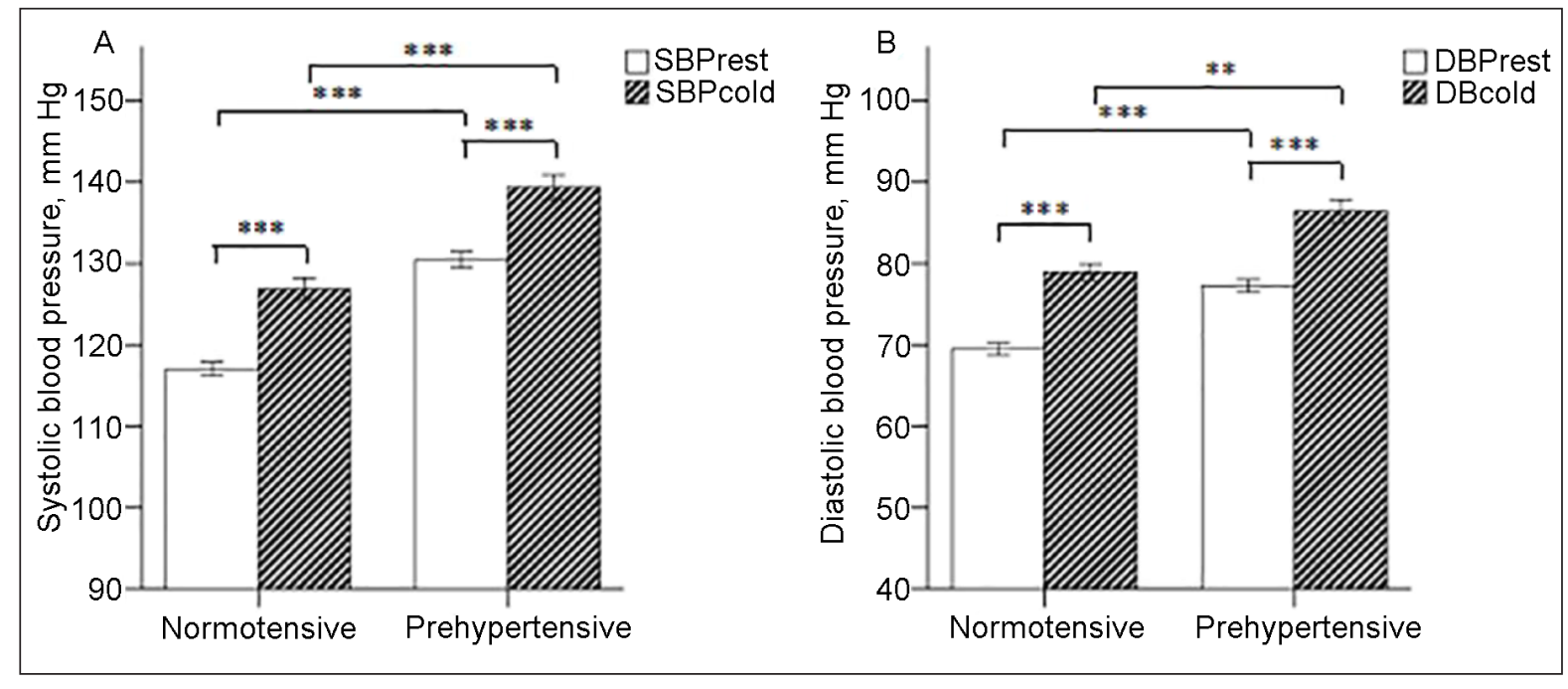

Fig. 1. Effect of 5-min cold pressor test on SBP (A) and DBP (B) in normotensive and prehypertensive subjects. ${ }^{* *} P<0.01 ;{ }^{* *} P<0.001$ were found from general linear model (GLM) two-way repeated-measure MANOVA. The data are expressed as means \pm SE 


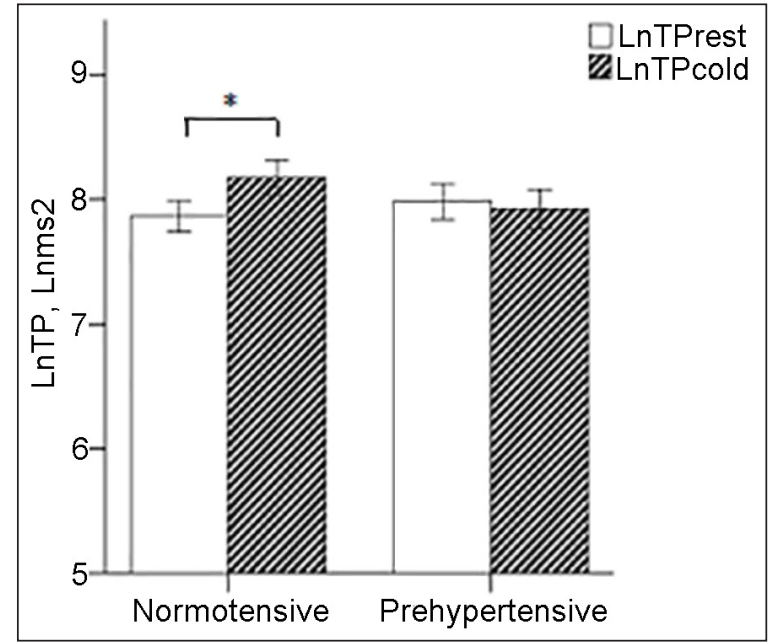

Fig. 2. Effect of a 5-min CPT on LnTP in normotensive and prehypertensive subjects. ${ }^{\star} P<0.05$ were found from general linear model (GLM) two-way repeated measures MANOVA. The data are expressed as means $\pm \mathrm{SE}$

When the BMI was taken into account and included as a covariate into analysis (MANCOVA), the results of pairwise comparisons between normotensive and prehypertensive groups did not change significantly (not shown).

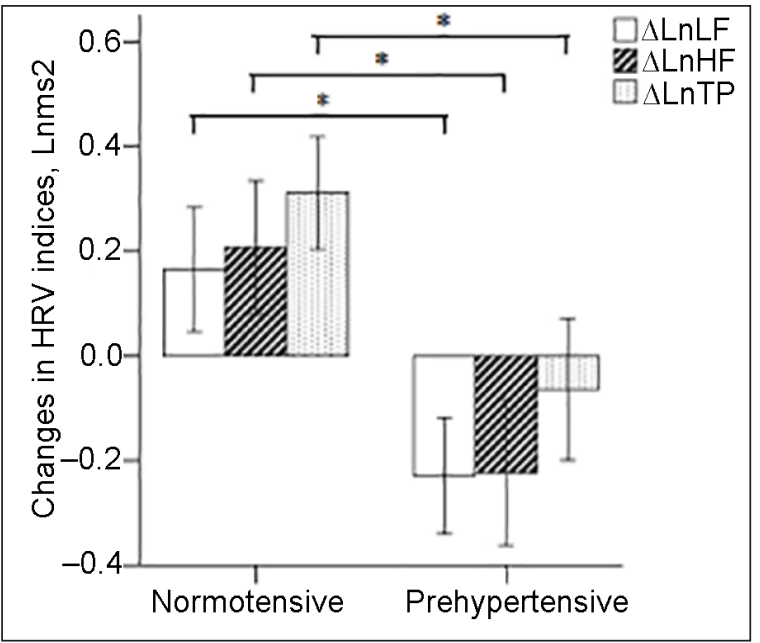

Fig. 3. Effect of a 5-min CPT on LnLF, LnHF, and LnTP responses in normotensive and prehypertensive subjects. ${ }^{*} P<0.05$ were found from general linear model (GLM) one-way MANOVA. The data are expressed as means $\pm \mathrm{SE}$

The multiple stepwise linear regression analysis revealed that SBP response on cold pressor test was positively associated with the BMI but not with prehypertension (Table, Model 1). At the same time, $\triangle \mathrm{SBP}$ was associated with $\triangle \mathrm{HR}$

Table. Predictors of SBP and DBP response to the CPT. Final stepwise regression coefficients of the models including centred variables and two-way interactions. The reference category was normotensive subjects

\begin{tabular}{c|c|c|c}
\hline Models & Unstandardized coefficients & Standardized coefficients & $P$ \\
\hline \multicolumn{4}{c}{ B Std. Error } \\
\hline
\end{tabular}

\begin{tabular}{|c|c|c|c|c|}
\hline & B & Std. Error & Beta & \\
\hline \multicolumn{5}{|c|}{ Model 1, Dependent variable: $\Delta$ SBPrest, $\mathbf{R}^{2}=\mathbf{0 . 3 3 2}$} \\
\hline (Constant, $\mathrm{mm} \mathrm{Hg}$ ) & 8.769 & 0.702 & & $<0.001$ \\
\hline$\Delta \mathrm{HR}^{\star} \Delta \mathrm{LnHF}, \mathrm{bpm}{ }^{\star} \mathrm{ms} 2$ & -0.677 & 0.158 & -0.449 & $<0.001$ \\
\hline$\Delta \mathrm{HR}^{\star}{ }^{\mathrm{LnLF}}$ Frest, $\mathrm{bpm}^{\star} \mathrm{ms} 2$ & -0.649 & 0.184 & -0.380 & 0.001 \\
\hline BMI, $\mathrm{kg} / \mathrm{m}^{2}$ & 0.457 & 0.191 & 0.248 & 0.020 \\
\hline \multicolumn{5}{|c|}{ Model 2, Dependent variable: $\triangle D B P r e s t, \mathbf{R}^{2}=0.320$} \\
\hline (Constant, $\mathrm{mm} \mathrm{Hg}$ ) & 8.715 & 0.655 & & $<0.001$ \\
\hline$\Delta \mathrm{HR}^{\star} \Delta \mathrm{LnHF}, \mathrm{bpm}^{\star} \mathrm{ms} 2$ & -0.676 & 0.151 & -0.482 & $<0.001$ \\
\hline$\Delta \mathrm{HR}^{\star}$ LnHFrest, bpm ${ }^{\star} \mathrm{ms} 2$ & -0.437 & 0.131 & -0.363 & 0.001 \\
\hline $\mathrm{BMI}, \mathrm{kg} / \mathrm{m}^{2}$ & 0.486 & 0.198 & 0.283 & 0.017 \\
\hline
\end{tabular}

$n=71 ; \Delta \mathrm{HR}$, heart rate response; $\Delta \mathrm{SBP}$ and $\Delta \mathrm{DBP}$, systolic and diastolic blood pressure responses; $\Delta \mathrm{LnHF}$, natural logarithm of high-frequency power responses; LnLFrest and LnHFrest, natural logarithm of low and high frequency power at rest; BMI, the body mass index. 
by means of resting LnLF: SBP and HR increased simultaneously only in the case of low values of baseline LnLF power. The $\triangle \mathrm{SBP}$ associated with $\Delta \mathrm{HR}$ also by means of $\triangle \mathrm{LnHF}$, thus SBP and HR increased simultaneously if LnHF decreased.

Similarly to $\triangle \mathrm{SBP}$, the $\triangle \mathrm{DBP}$ was positively associated with the BMI but not with PHT and was positively associated with $\triangle \mathrm{HR}$ if LnHF decreased (Table, Model 2). However, unlike $\Delta$ SBP, $\triangle \mathrm{DBP}$ was also associated with $\Delta \mathrm{HR}$ by means of resting LnHF power, such that DBP and HR increased only in the case of low resting LnHF power.

\section{DISCUSSION}

We investigated whether prehypertensive subjects have higher cardiovascular and HRV reactivity to a 5-min CPT compared with normotensive subjects and if it was possible to use the CPT as a predictor test of future hypertension. This work was a continuation of our previous investigation of the effect of the CPT on cardiovascular reactivity in normotensive and prehypertensive subjects (Shekh, 2018b). However, in the current research the duration of the CPT was $5 \mathrm{~min}$ to meet the main assumption of short-term HRV recording (Task Force of the European Society of Cardiology, and the North American Society of Pacing and Electrophysiology, 1996) and analyse variables of the HRV frequency domain during the CPT.

In the current study, the increment of SBP and DBP did not differ between normotensive and prehypertensive subjects. This finding is in agreement with some previous reports showing lack of differences in the increment of blood pressure during the CPT between normotensives and hypertensive subjects or even the blood pressure response was higher in normotensive subjects (Benetos, Safar, 1991; Czarkowski et al., 1994; Lambert, Schlaich, 2004; Shekh, 2018b). So, in congruence with these reports, we may conclude that cardiovascular reactivity to cold stress cannot be used as a predictor test of future hypertension. However, in some other reports an exaggerated cold pressor response was found as an indicator of atherosclerosis (Voudoukis,
1977) and a predictor of the severity of hypertension (Loyke, 1995). These contradictions might be solved as follows.

Similarly to the two-way repeated measure MANOVA, multiple linear regression analysis clearly indicated lack of relationship between the increment of blood pressure and the presence of prehypertension. However, there was a positive association between the increment and the BMI, such that the obese subjects demonstrated a higher blood pressure response to the CPT. Possibly that was why previous studies yielded inconsistent results with some showing higher and some showing the same and even lower blood pressure reactivity to the CPT in prehypertensive subjects or in persons with a family history of hypertension.

Despite the increments in SBP, DBP and HR were not different between normotensive and prehypertensive subjects, the mechanisms of an autonomic regulation were completely opposite. In the current study it was shown that LnTP, a measure of overall HRV, significantly increased in response to the immersion of the hand into ice-cold water only in normotensive subjects. Moreover, the increment of LnHF power indicating cardiovagal activity (Task Force of the European Society of Cardiology, and the North American Society of Pacing and Electrophysiology, 1996), the increment of LnLF power, a measure of sympathoinhibitory arm of baroreflex (Shekh, 2018a), and the increment of LnTP were significantly higher in normotensive subjects than in prehypertensive ones. Actually, the response of HRV indices to the CTP was "increased" in normotensive subjects and "decreased" in prehypertensive participants indicating low lability and an impaired autonomic nervous system response to the CPT in prehypertensives. Thus, $5-\mathrm{min} \mathrm{CPT}$ could be employed as a predictor test of future hypertension, allowing for early diagnostics.

In the subjects who demonstrated an increase in LnHF power indicating cardiovagal activity (Task Force of the European Society of Cardiology, and the North American Society of Pacing and Electrophysiology, 1996), in response to the $\mathrm{CPT}$, namely, normotensives, 
the blood pressure response was negatively associated with $\triangle \mathrm{HR}$, indicating normal baroreflex regulation. Meanwhile, the decrease in LnHF and cardiovagal activity found in the current study in prehypertensives was accompanied by a positive association between the increment of blood pressure and HR indicating impaired baroreflex regulation, in congruence with previous reports showing baroreflex impairment in hypertension and heart failure (Joseph et al., 2005; Chapleau, 2008).

In addition, in subjects with high values of baseline LnLF HRV power indicating, according to our hypothesis, sympathoinhibitory arm of baroreflex (Shekh, 2018a), $\triangle \mathrm{SBP}$ was negatively associated with HR response to the CPT indicating a normal baroreflex function. However, in the case of low resting LnLF power both SBP and HR increased. Similarly, the high values of resting LnHF power led to a negative association between HR and DBP response.

\section{CONCLUSIONS}

Despite the BMI but not prehypertension acting as a significant predictor of blood pressor response to a 5-min CPT, it could be employed as a predictor test of future hypertension, allowing for early screening for those prone to hypertension, by means of determination of LnLF and LnHF HRV power that increased in normotensive and decreased in prehypertensive subjects, indicating impaired autonomic regulation in the prehypertensive subjects.

\section{ACKNOWLEDGEMENTS}

We are grateful to Full Professor Valeriy Antonovich Bondarenko for his delicate leadership and given opportunity. Thanks Asya E. Zhuikova and Olga V. Vyazovska for technical support and the research participants for their enthusiastic participation, time, and patience with this study.

Received 30 June 2018

Accepted 13 December 2018

\section{References}

1. Benetos A, Safar ME. Response to the cold pressor test in normotensive and hypertensive patients. Am J Hypertens. 1991; 4(7): 627-9.

2. Chapleau MW. Arterial baroreflex. In: Izzo JL, Sica DA, Black HR, editors. Hypertension primer., 4th ed. 2008; 120-3.

3. Cheung SS. Responses of the hands and feet to cold exposure. Temperature (Austin). 2015; 2(1): 105-20.

4. Czarkowski M, Chojnowski K, OsikowskaLoksztejn M, Chodakowska J. Isometric exercise and cold pressor test in young men with a family history of essential hypertension. Pol Tyg Lek. 1994; 49(10-11): 225-7.

5. Farah K, Keshav G, Pawan S. Autonomic reactivity to cold pressor test in prehypertensive and hypertensive medical students. Indian J Physiol Pharmacol. 2011; 55(3): 246-52.

6. Goldstein DS, Bentho O, Park MY, Sharabi Y. Low-frequency power of heart rate variability is not a measure of cardiac sympathetic tone but may be a measure of modulation of cardiac autonomic outflows by baroreflexes. Exp Physiol. 2011; 96(12): 1255-61.

7. Joseph CN, Porta C, Casucci G, Casiraghi N, Maffeis M, Rossi M, Bernardi L. Slow breathing improves arterial baroreflex sensitivity and decreases blood pressure in essential hypertension. Hypertension. 2005; 46(4): 714-8.

8. Lambert EA, Schlaich MP. Reduced sympathoneural responses to the cold pressor test in individuals with essential hypertension and in those genetically predisposed to hypertension. No support for the "pressor reactor" hypothesis of hypertension development. Am J Hypertens. 2004; 17(10): 863-88.

9. Loyke HF. Cold pressor test as a predictor of the severity of hypertension. South Med J. 1995; 88(3): 300-4.

10. Mills KT, Bundy JD, Kelly TN, Reed JE, Kearney PM, Reynolds K, Chen J, He J. Global disparities of hypertension prevalence and control: a systematic analysis of population-based 
studies from 90 countries. Circulation. 2016; 134(6): 441-50.

11. Shaffer F, Ginsberg JP. An Overview of Heart Rate variability. Metrics and norms. Front Public Health. 2017; 5: 258.

12. Shekh VE. Sex and ethnic/racial differences in blood pressure and heart rate variability during orthostatic testing in young healthy individuals. J Phys Pharm Adv. 2016; 6(3): 846-59.

13. Shekh VE. LF HRV power as an index of sympathetic inhibition. FASEB J. 2018a; 32(1), supp.lb460.

14. Shekh VE. Increment in systolic blood pressure during cold pressure test is associated with baseline LF power in young prehypertensive men. FASEB J. 2018b; 32(1), supp.901.14.

15. Schroeder EB, Liao D, Chambless LE, Prineas RJ, Evans GW, Heiss G. Hypertension, blood pressure, and heart rate variability. The atherosclerosis risk in communities (ARIC) study. Hypertension. 2003; 42(6): 1106-11.

16. Task Force of the European Society of Cardiology, and the North American Society of Pacing and Electrophysiology. Heart rate variability. Standards of measurement, physiological interpretation, and clinical use. Eur Heart J. 1996; 17(3): 354-81.

17. Voudoukis IJ. Exaggerated cold pressor response: an indicator of arteriosclerosis. Angiology. 1977; 28(4): 248-55.

18. Wu JS, Lu FH, MD, Yang YC, Lin TS, MD, Chen JJ, Wu CH, MD, Huang $\mathrm{YH}, \mathrm{MD}$, Chang CJ. Epidemiological Study on the Effect of Pre-Hypertension and Family History of Hypertension on Cardiac Autonomic Function. J Am Coll Cardiol. 2008; 51(19): 1896901.

\section{Vera Evgenievna Shekh, Emeka Idot-Eyin Ofoegbu, Ebunoluwa Grace Adenuga, Larisa Semyonovna Shchyrova \\ NORMOTENZINİ IR PRIEŠHIPERTENZINI KRAUJOSPŪDİ TURINČIŲ VYRŲ SKIRTIN- GOS LF IR HF HRV REAKCIJOS İ ŠALČIO POVEIKIO TESTĄ}

\section{Santrauka}

Hipertenzija yra globali sveikatos problema, didinanti riziką susirgti širdies, smegenų kraujagyslių ir inkstų ligomis. Šalčio poveikio testas (CPT) yra naudojamas simpatinei nervų sistemai sužadinti, o HRV padeda ịvertinti autonominès nervų sistemos veiklą. Šio tyrimo tikslas buvo ịvertinti jaunų vyrų, turinčių normotenzinị bei priešhipertenzini kraujospūdi, širdies ir kraujagyslių bei ŽPV reakciją i CPT. Norint įvertinti HR, TP, LF ir HF reikšmes, 46 normotenzinị ir 25 priešhipertenzinị kraujospūdị turinčiu vyrų EKG buvo registruojama poilsio metu, o CPT - po 5 minučių. Standartiniu linijiniu modeliu buvo nustatytas $\mathrm{CPT}$ poveikis priešhipertenzinio kraujospūdžio HR, SBD, DBP ir HRV reikšmèms bei jų atsakui ị šaltị. HR, SBP ir DBP kintamieji ịvertinti pasitelkus daugkartinę linijinę regresinę analizę. Visi rezultatai ịvertinti naudojantis SPSS 22. Kraujospūdžio jautrumas CPT siejosi su BMI. Gautos HR, SBP ir DBP reikšmès normotenzinị ir priešhipertenzinị kraujospūdị turinčių asmenų statistiškai patikimai nesiskyrè. Pastebètos statistiškai patikimai didesnès LnTP, LnLF ir LnHF reikšmès normotenzinị nei priešhipertenzinį kraujospūdị turinčiu pacientų: normotenzinị kraujospūdị turinčių asmenų LnTP, LnLF ir LnHF rodikliai padidejo, o priešhipertenzinị kraujospūdị turinčių asmenų sumažèjo.

Raktažodžiai: priešhipertenzija, šalčio poveikio testas, HR 